\title{
ARTICLES
}

\section{PEACE AS A UNIVERSAL ISLAMIC VALUE*}

\author{
Mohammad Hashim Kamali*
}

\begin{abstract}
In many different ways the Qur'an and Sunnah bring peace into the heart of Islam's spirituality, law and ethics. There is a persistent quest to instil tranquillity into the hearts and minds of the believers. The thrust of this presentation is to explore and substantiate the grounds of our belief that peace is a universal and normative principle of Islam. An introduction raises the question as to why Islam is associated with violence, and whether there any basis for this. This is followed by discussion of Islam's self-definition and self-identification as a religion of tranquillity and peace. The sub-headings that follow are a reading of the source evidence, especially of the Qur'an and Sunnah. Then I take a glimpse into how in Islam Divine love and grace constitute the leitmotif and origins of God's creation. The discussion proceeds to expound the centrality of ihsān (beauty and benevolence) as a theological foundation of Islam. This is followed by a brief exposition of compassion (rahmah), justice ( $a d l$ ), human dignity (karāmah) and the vicegerency of mankind on earth (khiläfah) and how these feature in Islam as a religion of submission and peace. Then I explore the place of non-violence, forbearance and patience $(s a b r)$ in the teachings of Islam. Finally I turn to the use of force and the much-debated subject of jihād (selfless striving) under two sub-headings, one of which expounds textual dispensations and early developments on jihād, while the other examines jihād in the modern period. I show how the meaning of jihâd has been changing in tandem not only with juristic and theological thought but also with the politics of power, domination and conquest. I end with a conclusion and recommendations.
\end{abstract}

\section{Introduction}

Despite the presence of violence in many regions of the world involving many religions, the Western world associates Islam more than any other religion with violence. Past history and contemporary evidence show, however, that Islam has not witnessed to any more violence than one finds in other civilisations, particularly that of the West, as manifested in colonialism, World Wars I and II, and occupation and conflict in Iraq and Afghanistan. It seems that the historical memory of Muslim conquest of Spain and the Ottoman domination of Eastern Europe may account for Islam's association with force and power. Moreover, the upheavals of the past decades in the Middle East, and especially movements using the name of Islam and jihäd for political ends, have reinforced the idea 
prevalent in the West that in some special way Islam is related to violence. ${ }^{1}$

It is necessary to specify what is meant by violence. Dictionaries attach such meanings to the word as "swift and intense force", "rough or injurious physical force or action", "unjust or unwarranted exertion of force especially against the rights of others", and finally "injury resulting from the distortion of meaning or fact". The question can be asked as to how Islam relates to these definitions. As far as force is concerned, Islam is not completely opposed to its use, but rather seeks to control it under the rules of Sharī ah so as to curb criminality and unwarranted aggression. The Islamic concept of justice under the Sharī ah aims at restoring equilibrium and normality when these are destroyed. Despite all the wars and invasions which it experienced, Islam was able to create an ambience of peace and tranquillity which can still be felt wherever something of the traditional Islamic world survives.

As for violence as "rough or injurious physical force or action", the Sharī ah is also opposed to it except for self-defence or punishment of criminals. In the course of war, Sharī ah forbids injury to non-combatants, as I elaborate below. Punishment of criminals is the subject of adjudication by impartial tribunals, a matter which the Sharī ah has regulated in considerable detail.

With regard to the use of violence against the rights of others, Islam is not only opposed to it but seeks instead to protect all people's rights. What is remarkable, however, is not that some violence exists, as it does in this sense in most human societies including Muslim ones, but that despite so many negative social and economic factors, aggravated by colonialism, aggression, overpopulation, poverty and renewed western militarism as of late, "there is less violence as unjust exertion of force against others in most Islamic countries than in the industrialised West." "Finally, if by violence is meant "injurious distortion of meaning or facts", Islam is resolutely against it. Any distortion of truth is abhorrent to Islam, even if no one were to be affected by it. Falsifying the truth is especially objectionable when it causes injury to others.

Islam itself cannot be imposed on anyone through compulsion and violence (cf., $Q$ al-Baqarah 2:256). The Qur'an confirms that coerced religion would be pointless as it destroys the essence of conviction and belief. Muslims are enjoined to invite disbelievers "to the Way of Thy Lord with wisdom and beautiful preaching; and argue with them in ways that are best and most gracious...if you show patience, that is indeed the best (course)... For Allah is with those who restrain themselves, and those who do good" ( $Q$ al-Nahl 16:125-28). Explaining to his followers the need in some situations to undertake combat, the Prophet acknowledged God's revelation that warfare was wrong, indeed a "disliked" activity, yet it was necessary under some circumstances to fight persecution and injustice ( $Q$ al-Baqarah 2:216; al-Shürā 42:41). 
Furthermore, Islam identifies itself as a religion of moderation (wasatiyyah), and its moral teachings are grounded in keeping with the golden mean and avoidance of extremism. Even if force is to be used, it must be used in moderation and in proportion to the purpose sought. Only the aggressors are to be targeted, as the text proclaims: "There shall be no hostility except against the oppressors" (al-Baqarah 2:193) and that "if anyone is aggressive towards you, your response should be commensurate to the pain you have suffered ${ }^{3}$ (al-Baqarah 2:194).

\section{Peace as a Normative Principle In Islam}

As a positive concept peace connotes an enduring state of harmony, integrity, moderation and contentment. This is contrasted with negative peace, which merely denotes the absence of conflict. A positive notion of peace shifts the focus from only prevention of conflict and violence to a willingness to generate balance, inner tranquillity, and a just order of relations among individuals and communities. $^{4}$

Islam's intimate identity with peace begins with its name: Isläm means peace, which is also manifested in the daily greeting of Muslims: al-saläm 'alaykum 'peace be upon you.' "Al-Salām" is, moreover, one of the Most Excellent Names (al-asmā'al-husnā) of God. It is also significant that Muslims venerate the Prophet Muhammad and other Prophets with the typical phrase "peace and blessing be upon him." God the Most High praises those who act with humility and peace: "the servants of Allah most gracious are those who walk the earth with humility, and when ignorant people address them, they reply "Peace" ( $Q$ al-Furqān 25:63). The five daily prayers Muslims perform end with the salutation "peace be upon you," saluting first the right side of the world and then the left side of the world with the same words. This is further endorsed in the supplication-cumhadīth Muslims recite after ritual prayer: "O Allah! You are Peace; peace comes from you, and peace returns to you; so welcome us with the salutation of 'peace' and admit us into the Abode of Peace... ." Peace thus acquires a theological significance and partakes in a sparkle of the Divine, an important dimension of faith in Islam.

God's love and grace for His human servants is manifested in the creation of Paradise, the Garden of Peace, as their final destination, but due to an act of disobedience, as the Qur'anic narrative of first creation expounds, man's destiny took a different course. Yet divine revelation shows the way back to this place of all-embracing peace. Peace is a merit which the believers enjoy in Paradise: they reside there in God's pleasure "and greet one another with 'peace!'; they shall hear therein no vain or sinful talk, but only peaceful words" ( $Q$ Yünus 10:10; alWāqi'ah 56:25). 
God shows His human servants the path to seek Him, and whoever sets out upon that path is rewarded with inner tranquillity (sakinah) ( $Q$ Tawbah 9:26 \& 40) giving the seekers inner strength to build a peaceful environment. Peace comes from God, but not in an obvious way, as the Qur' an says: "He it is Who sent down tranquillity into the hearts of the believers... so that they might grow firm in their faith (in Him)" ( $Q$ al-Fath 48:4). Peace is thus to be found not outside the heart of man but primarily within it, and from here it spreads to the outer world. From the Qur'anic perspective, peace finds expression in three interlocking circles, the first of which is peace of the heart, which in turn nurtures peace with God and faith in Him, and this extends to the third circle: peace with the outside world. All three circles of peace constantly interact with and influence one another. ${ }^{5}$

The natural world is in a constant state of peace and submission, according to the Qur'an: it is muslim in surrendering itself (taslim) to the will of God, thus rising above all tension and discord ( $Q$ Al- 'Imrān 3:83; al-Tawbah 9:53). In its normative depiction of natural phenomena and the existential world, the Qur'an talks about stars and trees existing in a state of surrender or "prostration before God" ( $Q$ al-Rahmān 55:6). Tranquillity and repose thus become the normative order for God's creation, the beginning and end of all existence.

The instigators of violence and war are, on the other hand, condemned in the Qur'an as follows: "Whenever they kindle the fire of war, God extinguishes it. They strive to create disorder on earth and God loves not those who create disorder" ( $Q$ al-Mä'idah 5:64). Muslims are also directed not to decline the offer of peace whenever the opportunity arises to end a conflict: "If they (the opponents) incline to peace, you should also incline to it, and trust in God" ( $Q$ al-Anfäl 8:39).

\section{Universality of Peace}

The principle of Divine Oneness, tawhìd, is the first article of the Muslim faith and a major theme of the Qur'an. There is only one God and essentially one humanity, which implies that all humans are equal, simply because we are born of one man and one woman. "O mankind!" God says in the Qur'an, "surely We have created you from one male (Adam) and one female (Eve) and made you into tribes and nations so that you may come to know each other. The noblest of you with God are the most righteous among you" ( $Q$ al-Hujurāt 49:13). Tawhìd also teaches the unity of all being and urges Muslims to recognise the interconnectedness of all parts of God's creation, particularly of all human individuals and communities. The Qur'an calls on all people to cooperate in good deeds, and "cooperate not in hostility and $\sin$ " $(Q$ al-Má'idah 5:2), and then it also enjoins them to "vie with one another in good works; for to God you shall all return..." 
(5:48). Any effort made in order to resolve conflict and restore harmony among people, especially when it is made in the spirit of unity and cooperation, qualifies as the Qur'anic conception of "cooperation in good works - ta 'âwun."

Tawhìd is the basis of Islamic universalism, tolerance and inclusivity. People are all equal in the eyes of their Creator, irrespective of race, nationality, creed or gender. Nevertheless, the Qur'an is cognisant of internal diversity and pluralism among human communities and nations on account of language, creed, custom and culture. Tawhi $d$ is thus the governing principle that makes the Islamic outlook one of unity, inclusivity and universalism. ${ }^{6}$

The same tawhīdic approach is manifested in reference to the sanctity of human life. Every human life is equally important for humanity without discrimination of any kind. God has proclaimed that human life - a sacred gift - may never be taken without "just cause." If anyone takes the life of another human, unless in punishment for cases of murder and aggressive violence, it is as though he has killed all humanity. Likewise if anyone saves a life, it is as though he has saved all of humanity ( $Q$ al-Má'idah 5:32). The Sharī'ah thus protects every life and therefore seeks to establish safety and security ('amn, 'amān) of life for all and every member of the human fraternity.

\section{Divine Love and Mercy}

Islam is robustly monotheist in its belief in one transcendent God to Whom belong "all the beautiful Names", including the names of Beauty (jamāl), Majesty (jalāl) and Perfection $(k a m a \bar{l} l)$. The names of beauty take precedence over the names of majesty, for God says: "My mercy encompasses everything" ( $Q$ alA 'räf 7:156), and that "God has written mercy upon Himself" $(Q 6: 12,54)$. This is further endorsed by the renowned hadith of the Prophet that "God is Beautiful and loves beauty." As the ultimate source of peace and beauty, God transcends all opposites and all tensions and calls His servants to the permanent state of tranquillity in the Abode of Peace-Security (dār al-salām, $Q$ Yünus 10:25). Peace cannot be imposed from outside. It starts within the hearts and minds of people, and the dynamics it generates are externalised through compassion, generosity, forgiveness and cooperation in noble pursuits. ${ }^{8}$

God created the universe as a manifestation of His love and grace, aspects of His exalted self that underline His ninety-nine "Most Excellent Names". The Sufis expatiate on this and maintain that God's love for His servants also means that $\mathrm{He}$ is with them wherever they are; His face is turned to them whichever direction they face ( $Q$ al-Baqarah 2:115; al-Hadìd 57:4). He witnesses His servants who work for peace and justice, "and loves them for it never endingly". God's servants are enjoined never to give up hope that they will reach the Abode 
of Peace. "It may be that God will bring love (and friendship) between you and some of those whom you (now) hold as enemies. For God has power over all things. He is most forgiving, most merciful" ( $Q$ al-Mumtahanah 60:7). Muslims should be just and kind to all their fellow humans regardless of their faith, if they have not been aggressive nor driven the Muslims out of their homes $(Q$ al-Mumtahanah 60:8). A higher level of faith attainment is not only to avoid animosity and evil but "to repel evil with what is better" and thus build ties of affection and friendship ( $Q$ al-Shürā 41:34). The Prophet defined a Muslim as the person "from whose hands and tongues other Muslims [we may take this as referring to other humans] are safe". ${ }^{10}$

Every act of peace, however small, helps, for it is equivalent to praising the Creator and partaking in 'amal șâlih (righteous conduct). This is why the Prophet (pbuh) said: "Do not despise even the smallest deed, even if it consists of meeting your brother with a friendly encounter." 11 Friendly encounters radiate from a peaceful heart, which is averse to hostility and arrogance. "God has told me," said the Prophet Muhammad on another occasion, "that you should be humble; that none of you should raise himself above the other; and that none should treat the other unjustly."12

\section{Islām and Ihsāan (Benevolence)}

It is possible to act correctly in a manner which may nevertheless be devoid of spirituality and benevolence, practicing correct rituals unenlivened by an inner light. One can practice one's faith externally at the level of submission (isläm) yet be vacuous of sincere faith (imānn). One may also be religious in both these senses (isläm and $\bar{i} m \bar{a} n$ ) but lack spiritual beauty and virtue (iḩsān). The Qur'an repeatedly mentions God's love for the muhsinūn, those who practice iḥsān, and this is only possible when the existential reality of one's daily life is not overwhelmed by conflict. Peace thus becomes the prerequisite of beauty, indeed of comprehensive fulfillment of Islam.

The Qur'an is much more attentive to the internal dimensions of Islam than its externalities. The essence of being a decent, God-conscious, and benevolent Muslim receives greater attention therein. There is even a reference in the Qur'an denouncing those "performers of prayers who are absent-minded of the meaning of what they do, those who refuse to do a small act of generosity to the one in need" ( $Q$ al-Mā 'ūn 107:5). I hasān means beautiful conduct, being good to others, the striving for perfection in the sense of bringing out beauty in all that one does. Hence the utterance of the Prophet that "God has inscribed beauty in all things / inna Allāh kataba l-ihssāna 'alä kulli shay". ${ }^{13}$ One can perform the ritual prayer, for example, either as a deliverance of duty, or in a manner imbued with $i h s \bar{a} n$, 
the awareful state that one is standing in the presence of one's Creator. One can also commit reprehensible acts, such as talāq (divorce) in an ugly fashion, or in a decent manner (known in fiqh as țalāq ahsan). To state that God has inscribed $i h s \bar{a} n$ in all things is an incentive for us to discover it. For God loves Beauty, and the beauty of religion is ihsān.

A renowned hadith recorded in major collections recounts an audience of the Prophet with an enigmatic figure later identified as the angel Gabriel. While the Prophet was sitting in a circle of his companions, this stranger asked him to describe three concepts fundamental to Islam. The first was identified by the Prophet to be submission to God (isläm), which consisted of performing the five basic acts or pillars (arkān) of Islam. The second of these was faith (imānn), which the Prophet explained as having faith in God, His prophets, angels, the holy books, the day of judgment and God's knowledge of predestination. The third was spiritual beauty (ihssann), which meant one prays as though one sees God face to face, and even though one does not see God, one must know that He sees His servant. ${ }^{14}$

This striking dialogue indicates a structure of religious values that proceeds from the outer to the inner. Submission (isläm) is the first and most external feature, while the next two, namely faith and spiritual virtue, are affairs of the mind and heart, creating the basis for religious consciousness. To the extent that current interpretations and ritualistic practices of Islam exclude the internal aspects of faith and spiritual beauty, they present an impoverished picture of Islam. ${ }^{15}$

The Qur'anic conception of justice is also tempered with $i$ hsān: "God command justice and benevolence - al- 'adl wal-iḥsān" ( $Q$ al-Nahl 16:90.) Islamic justice must, in other words, be delivered in the spirit of $i h s \bar{a} n$, equity and fairness, and not of literalism consisting of measure-for-measure acts of retaliation and punishment.

\section{Human Dignity, Compassion and Justice}

Islam subscribes to a basic belief in human dignity as an expression of God's love for the most noble of His creation. According to the Prophet's Companion Ibn 'Abbās, God's unconditional bestowal of dignity on "the children of Adam" ( $Q$ al-Isrā' 17:70) was to honour and celebrate mankind's faculty of reason, which is the hallmark of his dignity above the rest of God's creation. ${ }^{16}$ This also qualified mankind to be the recipient of divine revelation. Man has been created in the most beautiful form (ahsan al-taqwim) ( $Q$ al-Tin 95:4) both physically and spiritually, endorsed further by God's affirmation: "I breathed into him [Adam] of My Spirit" ( $Q S \bar{a} d$ 38:72). God Most High then ordered the angels to prostrate 
themselves before Adam, which they did, thus establishing the highest rank of spiritual dignity for the progeny of Adam ( $Q$ al-A 'räf 7:11). This metaphysical optimism designates human beings as God's vicegerent on earth (khaliffat Alläh $f_{i}$ l-ard) with a mission to share the earth with God's other creatures, promote good, prevent evil and establish justice. ${ }^{17}$ God requires human beings to behave with dignity, which entails a great deal, e.g., that one does what one says, speaks the truth, and exercises mercy and compassion. Dignified conduct also entails respecting one's fellow humans, giving everyone what is due, and nurturing a caring attitude towards the earth's natural environment.

Justice (' $a d l$ ) must be done and evil fought through proportionate effort and use, if necessary, of force, yet Muslims are normally enjoined to be kind to everyone at all times: "Allah commands justice, the doing of good, and liberality to kith and kin, and He forbids all shameful deeds, injustice and rebellion" ( $Q$ al-Nahl 16:90). Thus ' $a d l$ is the starting point and key to establishing harmony in family and society. Peace is not sustainable in the face of oppression and injustice; hence, justice becomes a prerequisite of sustainable peace. Indeed, in order of Islam's priorities justice stands next to tawhìd, and like tawhīd it is also universal in that it must transcend all considerations of gender, race and religion (Q al-Mä'idah 5:8).

Mercy (rahmah) and forgiveness ('afw) also rank high in the Islamic order of values. God, His Prophet, and the Qur'ān all associate themselves intimately with merciful compassion: al-Rahmān al-Rahìm (Most Compassionate, Most Merciful) are the two most favoured of God's Excellent Names, as they also head every one of the 114 chapters of the Qur'an. The Qur'an characterises itself as a mercy to the believers (10:57) and the Prophet Muhammad as "a mercy to the world" (Q al-Anbiya ' 21:107). In a renowned hadìth the Prophet declared: "One who does not show mercy to people, God will not be merciful toward him," 18 and another hadìth states "People are God's children, and those dearest to God are the ones who treat His children kindly."

Forgiveness ('afw), which features prominently in the Qur'ān and hadith, is meant to overcome animosity among people, enabling them to reconcile their differences and live a peaceful life. Forgiveness must counter and vanquish hatred; for the Qur'ān characterises true believers as those who forgive when they are angry ( $Q$ al-Shīra $42: 73)$. Believers are further advised to "keep to forgiveness, enjoin kindness, and turn away from the ignorant" ( $Q$ al- $A$ 'ra $\bar{f}$ 7:199). Thus if someone annoys one out of ignorance, it is better not to confront him but to turn away and seek peace. People of distinctively virtuous character are those who can "repel evil (not with evil) but with something better, that is, with amnesty and forgiveness" ( $Q$ al-Mu'minūn 23:96). To win the people's hearts is deemed the highest of virtues in Islam. The Prophet is reported to have 
addressed his Companions: "Should I inform you of something that is better than prayer, fasting and pilgrimage", and the Companions were eagerly listening: "It is to reconcile and bring peace among two parties (ișlāh dhāt al-bayn)." ${ }^{20}$ The effort to bring reconciliation and peace often necessitates eliminating the grounds of strife and conflict. Hence peace, not war, is God's true purpose for creation and the normative principle of Islam.

\section{Non-Violence and Patience (al-Șabr)}

There is evidence to suggest that the Shari' ah allows only defensive war and deterrence of impending aggression, if necessary by force, yet in all cases prescribes moderation, forbearance and patience. Doing no greater violence than the minimum necessary and "not transgressing limits" are repeatedly stressed in the Qur'an. Deterrence is achieved by doing to the aggressor what he has done to the innocent. Muslims are enjoined that they should respond to provocations with patience and efforts to facilitate conciliation, because forgiveness and restoration of peace remains the preferable options ( $Q$ al-Shürā 42:40-43).

Of the twenty-three year period of his mission, The Prophet (pbuh) spent the initial thirteen of these twenty-three years in Mecca, where he conducted his campaign with peace and nonviolence. When he was persecuted during the Meccan period, he used to pray, "Forgive them Lord, for they know not what they do." Later in the eighth year after the hijrah when the Prophet conquered Mecca with his followers, he set an exemplary record of forgiveness toward Meccans who had bitterly fought him for many years. He even showed mercy to Abū Sufyān's wife Hind bint 'Utbah, who was under a death sentence for having brutally mutilated the body of the Prophet's beloved uncle Hamzah during the battle of Uhud five years earlier. ${ }^{21}$ When some of his Companions asked him to invoke the wrath of God upon the Meccans because of their persecution of Muslims, his reply was: "I have not been sent to curse anyone but to be compassionate to all." ${ }^{22}$ A saying in Islamic ethics similarly declares that "the most gracious act of forgiving an enemy is when one has the power to take revenge." ${ }^{23}$

As for the meaning of the frequently recurring phrase in the Qur'ān, fi sabì Alläh (in God's way), it is related that a number of the Companions were sitting with the Prophet when a muscular man from the pagans of Quraysh came into view. Some of them exclaimed, "If only he would use his strength in the way of God!" The Prophet then asked: "Do you think only someone who is killed in battle is engaged in the way of God?" He continued: "Whoever goes out in the world seeking licit work to support his family, he is on the path of God; whoever goes out in the world to support himself is on the path of God; whoever goes out seeking worldly increase (al-takäthur) has embarked, however, on the way of the devil." ${ }^{24}$ 
This is a clear rebuttal of those who understand striving in the way of God in primarily military terms. Al-Bukhārī and Muslim have also recorded the hadīth: "one who helps widows and the poor are like fighters in the path of God."25

On the virtue of patience featuring prominently in the Qur'ān, the ninth century work of Ibn Abi al-Dunyā (d. 894) entitled Al-Sabr wa'l-Thawāb 'Alayhi contains the following hadìth on the authority of the Companion 'Ișmah Abī Hukaymah: ${ }^{26}$

God's Messenger (pbuh) wept so we asked him, "What has caused you to weep, O Messenger of God?" He replied, "I reflected on the last of my community and the tribulations they will face. But the patient from among them who arrives will be given the reward of two martyrs."

Sufyān b. 'Uyaynah also reported the Prophet's utterance: "The believers have not been given anything better and more meritorious than patience, by means of which they enter Paradise." ${ }^{27}$ According to another hadith on the authority of 'Alī b. Abī Tạalib: ${ }^{28}$

God's Messenger (pbuh) said: "Patience is of three kinds: long-suffering during tribulations, patience in obedience to God, and patience in avoiding sin. Whoever remains patient during tribulation until he averts it by the seemliness of his forbearance, God will ordain for him three hundred levels of recompense...."

\section{Use of Force and Jihād}

Jihäd or "struggle for a higher cause" has been extensively treated in existing literature, and our remarks merely address this topic in two segments: textual and early developments, and jihäd in the modern period.

A. Text \& Early Developments. The Prophet migrated to Madinah to escape the hostility and persecution which he and his small number of followers had endured at the hands of the Meccan pagans. He set up the first Muslim polity in Madinah; hence the Madinan verses of the Qur'ān began to address legal matters as well as defence against continued Meccan hostilities. In 624, two years after the migrations of Muslims to Madinah, "in which the Quraysh continued to persecute them and then led armies against them, Muhammad (pbuh) finally announced a revelation from Allah that Muslims were allowed physically to defend themselves. ${ }^{.29}$ A specific Qur'ānic verse was then revealed ( $Q$ al-Hajj 22:39):

Permission [to fight] is given to those against whom war is being wrongfully waged, and indeed God has the power to help them. Those who have been driven from 
their homes against all right, for no other reason other than their saying that "only God is our Lord and Sustainer."

This was the first grant of permission in the Qur'ān. ${ }^{30}$ Yet Muslims were still not allowed to engage in fighting during the months of pilgrimage ( $Q$ alBaqarah 2:217). The Qur'ān also enjoined upon Muslims to defend those who were oppressed and who cried out to them for help ( $Q$ al-Nisa $\left.\bar{a}^{\prime} 4: 75\right)$. Thus it was implied that Muslims could resort to defensive combat even on behalf of Christians and Jews who were the object of Meccan hostility. ${ }^{31}$ In the verse alShürā 42:40 self-defence was allowed but not through violent means, only to repel the enemy's oppressive and immoral behaviour. In the verse al-Hajj 22:39 a more explicit reason is given: wrongful expulsion of Muslims from their homes. Only when both just cause and right intention were present, did war in selfdefence against the aggressor become obligatory (see $Q$ al-Baqarah 2:216). Yet the majority of Muslim jurists has held that the call for jihād can be issued only by a legitimate Muslim leader in Muslim majority lands. Whereas jihād for selfdefence need not be formally declared as such, all other legitimate jihād should be preceded by fair warning and declaration of intent. ${ }^{32}$

Before assigning a leader to military expeditions, the Prophet would instruct him to fight honourably, not to hurt women and children, not to harm prisoners, nor to mutilate bodies, plunder, or destroy trees or crops. ${ }^{33}$ After the Prophet's death his close friend and successor the Caliph Abu Bakr announced the following code of conduct to Muslim warriors: ${ }^{34}$

Do not act treacherously; do not act disloyally; do not act neglectfully; do not mutilate; do not kill children nor old men; do not cut off the heads of the palmtrees nor burn them; do not cut down the fruit trees; do not slaughter a sheep or a cow or a camel, except for food. You will pass by people who devote their lives to worship in cloisters; leave them alone. You will come upon people who will bring you platters in which are various sorts of food; if you eat any of it, mention the name of God over it.

The Qur'ān did not permit initiation of hostilities, as in verse al-Baqarah 2:190: "Fight in the cause of God those who fight you, but do not commit aggression, for God loves not aggressors." Recourse to armed comb at must therefore be in response to a prior act of aggression by the opposing side. As one commentator observed, the verses that talk of combat "are clear that war is only permissible against those who are waging war; and the enemy in combat... as well as those acting unjustly to prevent Muslims from practicing their faith... No one else is to be harmed." ${ }^{35}$

During the month of Ramadān in $624 \mathrm{CE}$ the pagans of Mecca attacked the Muslims in what became known as the Battle of Badr. Two years later the Battle 
of Uhud was fought wherein the Muslims suffered severe losses, followed by the Battle of Khandaq in 627. Apart from these three major battles, a large number of minor campaigns were fought until the Prophet's death in 632. Some of the most trenchant verses exhorting the Muslims to fight were revealed on the occasion of these major military campaigns. One such verse is al-Tawbah 9:5, known as the sword verse (ayat al-sayf), which stated: "when the sacred months are over, slay the polytheists wherever you find them, and take them captive and besiege them...." The explicit reference to polytheists (mushrikin) who may be fought after the end of the sacred months, highlighted the application of this verse to the pagan Arabs at that time. This is how many leading legal scholars including alShāfi 'i and al-Ṭabarī understood this verse. ${ }^{36}$ A contemporary observer similarly comments that the advice of these verses may well seem "out of place in a religious context, but they are not out of place in the context of what a military commander says before a battle.... That was precisely the context of those particular revelations. ${ }^{37}$ The commentators are in agreement on the occasion of revelation of the sword verse: seven years after the exodus of Muslims to Madinah when the Prophet negotiated a truce with the pagans of Mecca known as the Treaty of Hudaybiyah. One year later the Meccans violated the terms of this treaty and then this verse was revealed. The latter portion of the verse still added the proviso: "If they repent and take to prayer... let them go their way. God is much forgiving, a dispenser of grace ( $Q$ al-Tawbah 9:5)." ${ }^{\prime 38}$

During the Umayyad period (661-750) the constant border skirmishes with the hostile Byzantines predisposed Syrian and Iraqi jurists in particular to endorse the concept of an offensive jihäd. "It would not be an exaggeration to state," Afsaruddin states, "that to express support for expansionist war at this time was to proclaim one's support for the existing government." ${ }^{\text {"39 }}$ In contrast, Madinan and Meccan jurists placed greater emphasis on religious practices such as the pilgrimage, prayer and mosque attendance. ${ }^{40}$

By the early 'Abbāsid period (ca. late $2^{\text {nd }} / 8^{\text {th }}$ century CE) the military aspect of $j i h \bar{a} d$ began to receive greater emphasis in certain official and juridical circles. Jiha $\bar{a}$ from this period on was progressively conflated with qitāl (combat), collapsing the distinction that the Qur'ān maintains between the two. ${ }^{41}$ Many jurists also invoked the tool of naskh (abrogation), especially by the sword verse ( $Q$ al-Tawbah 9:5) in support of their assertions. An exaggerated claim was thus made that this verse abrogated all the previous verses of the Qur'ān regarding peace, perseverance, patience, moderation, forgiveness and tolerance, etc., and that no less than 114 (some reckon 140) verses were consequently abrogated by this single verse. One of the most important verses also claimed to have been abrogated by the sword verse is al-Baqarah 2:256, which proscribes compulsion in religion. This simplistic view was by no means accepted by all. Two celebrated 
Qur'an exegetes, al-Ṭabarī (d. 923 CE) and Ibn Kathīr (d. 1373), maintained that this verse had not been abrogated and remained valid for all times. ${ }^{42} \mathrm{~A}$ contemporary observer also draws the conclusion that most Islamic authorities outside the era of the war-filled medieval period are firm in their judgment that the warlike verses in the Qur'an, even those "revealed very late in Muhammad's mission, do not cancel out the overwhelming number of verses that extol tolerance, reconciliation, inclusiveness and peace." ${ }^{43}$

The foregoing helps to explain the juristic construction over dividing the

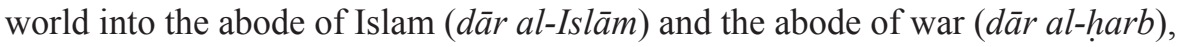
the latter referring to non-Muslim territories. Without entering into detail, it may be observed that many jurists have added to this the more peaceable divisions:

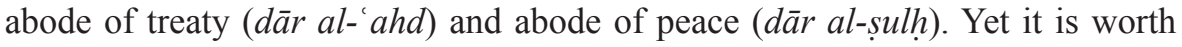
emphasising that the concept of dār al-harb has no basis in the Qur'ān or the Prophet's Sunnah. ${ }^{44}$

B. Jih $\bar{a} \boldsymbol{d}$ in the Modern Period. The meaning of jihăd had in course of time been changing from an intellectual and spiritual struggle to fight the evil within oneself and without, to one that is decidedly militarist. Much of this change has taken place in tandem with the turbulent course of political domination, colonialism and conquest. The reason for this shift in meaning becomes quite clear when one looks at developments in late nineteenth and early twentieth centuries. In just a few decades, nearly the whole Muslim world was attacked, invaded and occupied by non-Muslim nations. The Ottoman Empire, the last major Muslim power, was destroyed in World War I, and almost all the Muslim states that arose from its ashes were colonised by Britain, France or Italy. Russia and the subsequent Soviet Union also crushed Muslims in Central Asia during the Basmachi Revolt (1916-23), the Turco-Islamic uprising against Russian and then Communist rule. Sustained and successive foreign invasions of Muslim nations impacted the entire intellectual landscape of Islam. The West was no longer seen as a model to emulate but rather an intruder to eradicate. The push for intellectual reconstruction and ijtihād advocated by al-Afghānī, 'Abduh and others was overshadowed by the drive for $j i h \bar{a} d .{ }^{45}$

Nikkie Kiddie, an American professor of Middle Eastern history, observed that militant jihäd movements of the modern era began and grew mostly as a response to Western colonialism. In the nineteenth century, expansive waves of jihäd movements emerged in Algeria, Sudan, the Caucasus, and Libya as "a direct response to French, British, Russian and Italian colonial conquests." ${ }^{46}$ The eminent historian of the Middle East Bernard Lewis also wrote: "At no point do the basic texts of Islam enjoin terrorism.... At no point do they even consider the random slaughter of uninvolved bystanders." ${ }^{\text {47 }}$ Muslim scholars have 
unambiguously opposed the intentional killing of non-combatants, because the Qur'ān bids: "Fight in the way of God those who fight you, but do not go beyond the limits" ( $Q$ al-Baqarah 2:190). The Prophet also ordered troops not to kill the very old, the infant, the child or the woman. Bernard Lewis added: ${ }^{48}$

Fighters in a jihād are enjoined not to kill women, children and the aged unless they attack first, not to torture or mutilate prisoners, to give fair warning of the resumption of hostilities after a truce, and to honor agreements. The medieval jurists and theologians discuss at some length the rules of warfare, including questions such as which weapons are permitted and which are not.

The medieval Islamic concern for moral warfare is most apparent when contrasted with some of the wanton killing committed by certain enemies of Muslims, such as the Mongol invaders and the Crusaders. When the Crusaders sacked Jerusalem in 1099, they indiscriminately slaughtered the local population; as Karen Armstrong remarks: "They killed all the Saracens (Muslims) and the Turks they found.... They killed everyone whether male or female." ${ }^{49}$

In return, Muslim forces led by Saladin not only spared noncombatants but also released many prisoners of war. When Saladin reconquered Jerusalem in 1187, the city was unharmed and only the "Franks" or Christians from Europe were expelled, whereas Eastern Christians were allowed to stay. A modest ransom was assessed, but those who could not afford it were excused. ${ }^{50}$ In this way he was behaving simply as a Muslim ruler who abided by the Shari' ah.

The religious fanatics who resort to senseless violence "did not come out of the blue. The political history of the past two centuries of Islamdom holds the key to their emergence. What this also means is that Islamism and its violent offshoot, jihadism, is more of a political phenomenon than a religious one."'51 The widespread hostility among Muslims to Western aggression and dominance has sometimes led even religiously indifferent but politically irritated Muslims to sympathise with the jihadists. "Even young Arab girls in tight jeans," an American scholar observed, "praise bin Laden as an anti-imperialist hero." 52 The situation has worsened since the September 11 attacks and the aftermath of violence in Afghanistan, Iraq, Kosovo, Palestine and elsewhere. Western Christian missionary activity, supported as it is directly or indirectly by the might of the West and the renewed zeal of the Christian Right movement, now poses a major challenge for contemporary Muslims dealing with Western Christianity, in contrast to local forms of Christianity with which Muslims have lived usually in peace for centuries. ${ }^{53}$

The root causes of some of the present day conflicts have very little to do with religion even if they may appear to have some religious implications. 
The Israeli-Arab conflict is about land, dispossession and the right of selfdetermination, even if some Jewish, Christian and Muslim fanatics are exploiting the issue for their own ends. The conflict in Kashmir is also about the right of self-determination. It is not a Hindu-Muslim war. The Sinhala-Tamil conflict is similarly not a Buddhist-Muslim conflict. It is well-known that Buddhism has been dragged into the conflict by only a small number of Buddhist monks. The Mindanao conflict in the Philippines is not about religion, it is about land and historical rights as well as unemployment and poverty, though religious sentiment then entered into the conflict. ${ }^{54}$ The Maluku conflict in Indonesia arose out of socio-political and economic circumstances, not a fight between Islam and Christianity. ${ }^{55}$

Arthur Schneier, who convened four religious summits on peace and tolerance in the former Yugoslavia, asserted that "in our era, religion is not the cause of conflict, although it is often used as an excuse; religion, unfortunately is often the most visible difference between contesting groups and, as a result, is frequently blamed for conflicts.... A crime committed in the name of religion is the greatest crime against religion." ${ }^{" 56}$ Feisal Rauf has also commented: "It is a travesty of religion, of God's directives to humanity, to be brutal, cruel and inhumane in God's name....It is essential that the Cross, the Crescent and the Star of David become symbols of peace, tolerance and mutual respect." ${ }^{57}$

\section{Conclusion and Recommendations}

Broader Concerns: Peace is a universal objective and difficulties in its realisation concern people in all corners of the globe. The state of tension that has prevailed since post-September 11, 2001 has served to heighten awareness of the need for greater cooperation among people to vindicate peace. Senseless wars, border clashes, military occupation, the arms race and suicide bombings have not only failed to resolve any conflict, they have added to the size of the challenge. The fall-out of wars in many parts of the world that we are currently witnessing is draining the resources of the world, adding to frustration and deprivation. This serves as a stern reminder of the following:

- The sanctity of human life and dignity, the most cherished values of human civilisation, is rooted in spirituality and ethics which in turn have been concretised in a set of legal rules. Yet for legal rules to be effective, their grounding in religion and ethics should be made more visible. Islam's teachings on peace, forgiveness, compassion, justice and social harmony should be integrated into our approaches to holistic education, good governance and international law.

- There is enough evidence in the Qur'an and hadith to support the conclusion that world peace is one of the higher goals and objectives or 
maqāsid of the Sharī'ah. Should there be any aspects of fiqh that depart from the spirit of this objective, they should be duly revised through ijtihād-oriented efforts.

- Jihād is a powerful part of Islamic teachings that can mobilise Muslims to combat oppression and injustice. Yet the military overtones of jihād have almost totally suppressed its more peaceful purposes. A state of imbalance that has come about as a result calls for a corrective through education and media that should also enlist the support of religious leaders and 'ulama'.

- Western media is not helping the cause of peace by spreading Islamophobia and false premises that link Islam with terrorism and violence. Negative propaganda should stop. Truth should be told, and constructive criticism made. It is necessary for Western media to turn a page and assist their Muslim counterparts in the true spirit of "cooperation in pursuit of good deeds".

- Media in the OIC countries should design suitable programmes to correct negative perceptions of Islam. Malaysia can play an important role in this effort. The OIC should also set up an international institute of peace studies with a combined agenda of study and research in Islam and traditions to develop active programmes of public engagement and publications.

- Security and peace are inter-related but two different themes. Basic security relates to observance of people's rights and the effort it takes to make people safe as they go about the business of everyday life. It has also much to do with economic development and democratisation.

\section{Practical Proposals}

- Our political leaders and officials should make peace-building a feature of their engagements, generate ideas and develop public support for a common peace agenda between Islamic and Western countries.

- Our religious leaders, 'Ulama', judges and Muftis, 'ulama' associations and civil society should draw attention to persistent violence, insecurity and conflict, instead of focusing on such issues as hudūd punishments or on what people eat and wear.

- The 'Ulama' associations of Malaysia and other Muslim countries should engage in consultations with prominent figures among them to work on an agenda such as "Peace Building as the Jihäd of the $21^{\text {st }}$ century".

- Malaysia should solicit support, initially from Turkey, Egypt, and possibly Morocco, to promote a "Common Peace Agenda" between Islamic and 
Western countries, the US and Europe. This may involve mediation to help resolve local conflicts in countries such as Afghanistan, Pakistan and Palestine. Having successfully brokered peace in the Philippines, nations such as Malaysia are in a favourable position to take other initiatives. Formation of a group of eminent persons from select Muslim countries may also seem advisable.

In mid-2011 IAIS-Malaysia introduced its new feature programme, "PeaceSecurity and Islam", consisting of forum presentations, publications and a website feature. The Institute of Diplomacy and Foreign Relations (IDFR) and the Cordoba Foundation of London have more recently welcomed and joined hands with IAIS Malaysia in this venture. We hope to continue the endeavour and expand it with cooperation from individuals and institutions in this country and abroad.

\section{Notes}

* This is a revised version of my paper presented at the Forum "Peace and Security: Islamic Perspectives" jointly organised by the International Institute of Advanced Islamic Studies (IAIS) Malaysia, and the Institute of Diplomacy \& Foreign Relations (IDFR) in Kuala Lumpur 4 October 2011.

** Mohammad Hashim Kamali, Founding Chairman and CEO of IAIS Malaysia, graduated from Kabul University, and took his PhD in Islamic and Middle Eastern Law at the University of London in 1969. Professor Dr M.H.Kamali served as Professor of Islamic Law and Jurisprudence at the International Islamic University Malaysia (IIUM, 1985-2007), then Dean of the International Institute of Islamic Thought and Civilization (ISTAC). He also held Visiting Professorships at McGill University's Institute of Islamic Studies; Capital University, Ohio; and the Wissenschaftskolleg, Berlin. A member of the Constitution Review Commission of Afghanistan (2003), he has provided expert legal consultation to the new constitutions of Iraq, the Maldives and Somalia. Eminent authority on Islamic legal studies, he has published over 150 academic articles and 35 texts, including standard textbooks at universities worldwide.

1. See Seyyed Hossein Nasr, "Islam and the Question of Violence," in Aftab Ahmad Malik, ed., With God on Our Side, Policies and Theologies of the War on Terrorism (Bristol, UK: Amal Press, 2005) 273.

2. Ibid., 275 .

3. See for details, Mohammad Hashim Kamali, Moderation and Balance in Islam: the Qur'anic Principle of Wasatiyyah (Kuala Lumpur: IAIS Malaysia, 2010) $5 \mathrm{ff}$.

4. See Ibrahim Kalin, "Islam and Peace, a Survey of the Sources of Peace in the Islamic Tradition," in Qamar ul-Huda, Ed., Crescent and Dove: Peace and Conflict Resolution in Islam (Washington DC: United States institute of Peace, 2010) 7-8.

5. Consult Mahmoud Zakzouk, On Philosophy, Culture and Peace in Islam, Andreas Bsteh, Ed., English trans. from the German (New Delhi: Vikas Publishing House, 2004) 126-7.

6. See Ayse Kadayifci-Orellana and Meena Sharify-Funk, "Muslim Women Peacemakers and Agents of Change," in Qamar ul-Huda, Crescent and Dove, 190.

7. Muslim, Mukhtașar Șahīḥ Muslim, Muhammad Nāṣir al-Dīn al-Albānī, ed., (Beirut: al-Maktab alIslāmī, 1987/1407, $6^{\text {th }}$ ed.) v. $1,20 \S 54$.

8. See Mahmoud Zakzouk, On Philosophy, Culture and Peace in Islam, 115.

9. Ibn al 'Arabī, cited in William Chittick, The Self Disclosure of God; Principles of Ibn al- 'Arabi's Cosmology (Albany: SUNY Press, 1998) 22.

10. Muslim, Mukhtașar Șahịh Muslim, v.1, 23 §69. 
11. Ibid., $474 \S 1782$.

12. Ibid., v.4, §2199.

13. Ibid., $338 \S 1249$.

14. Sahịh Muslim, Kitāb al-īmān, Chap. $1, \S 1$.

15. See Carl W. Ernst, "Demystifying the Rhetoric of Civilisational Conflict," in Thomas W Simon \& Azizan Baharuddin, Eds., Dialogue of Civilisations and the Construction of Peace (Kuala Lumpur: University of Malaya, Centre for Civilisational Dialogue, 2008) 2; see also Imam Feisal Abdul Rauf, What's Right With Islam Is What's Right With America (HarperSanFrancisco, 2004) 61.

16. See Mohammad Hashim Kamali, The Dignity of Man: An Islamic Perspective (Cambridge and Kuala Lumpur, 2002) xvii.

17. See Ibrahim Kalin, "Islam and Peace, a Survey of the Sources of Peace in the Islamic Tradition", 11.

18. al-Khāțīb al-Ṭabrīzī, Mishkāt al-Mașābīh, v. 3, §4678.

19. Ibid., v. $2, \$ 2724$.

20. al-H̄āfiz Aḥmad b. Ḥusayn al-Bayhaqī, Shu' ab al-Īmān, M.S. Basyūnī Zaghlūl, Ed. (Beirut: 1990) v. 7, $490 \S 11092$.

21. Ibn Jarīr al-Tabarī, Ta 'rīkh al-Rusul wa l-Mulūk, v. 8, 182.

22. Ibid.

23. See Muhammad Abu-Nimr, "An Islamic Model of Conflict Resolution," in Qamar ul-Huda, Crescent and Dove, 84.

24. 'Abd al-Razzāq al-Ṣan'ānī, al-Mușannaf, Ḥab̄īb al-Raḥmān al-A 'ẓamī, Ed. (Beirut: al-Maktab alIslāmī, 1970) v. 5, 272.

25. A. J. Wensinck, Concordance et Indices de la Tradition Musulman (Leiden: E. J. Brill, 1936-1969) v.1, 389; cited in Asma Afsaruddin, "Challenging Statist-Military Perspectives. The Early Semantic Purview of Jihād and Martyrdom," in ed. Qamar Ul-Huda, Crescent and Dove, 48.

26. Ibn Abī al-Dunyā, al-Ṣabr wa l-Thawāb 'Alayhi, Muḥammad Khayr Ramaḍān Yūsuf, Ed., (Beirut: Dār Ibn Hazam, 1997) 85; as cited by A. Afsaruddin, "Semantic Purview of Jihād", 51.

27. Ibid., 51.

28. Ibid., 31.

29. Joel Hayward, Qur'anic Concepts of the Ethics of Warfare: Challenging the Claims of Islamic Aggressiveness (London: Cordoba Foundation Occasional Papers, 2011) 12.

30. Ibid.

31. Muslim historians record that there were pagan tribes who never fought the Prophet, but were rather allies of the Muslims, and that Muslims fought on their behalf.

32. See for details, Mohammad Hashim Kamali, "Jihād and the Interpretation of the Qur'ān: Contextualising Islamic Tradition", in M Cherif Bassiouni \& Amna Guellali, Ed., Jihad and its Challenges to International and Domestic Law (The Hague: Hague Academic Press, 2010) 39-58; and Joel Hayward, Qur'anic Concepts, 19.

33. Imām Muhammad Shirazi, War, Peace and Non-Violence: An Islamic Perspective (London: Fountain Books, 2003) 29.

34. Fred M. Donner, The History of al-Tabari (Ta'rīkh al-rusul wa l-mulūk), Vol. 10 The Conquest of Arabia (Albany: State University of New York Press, 1993) 16.

35. Joel Hayward, Qur'anic Concepts 16.

36. Muhammad b. Idrīs al-Shāfi’̄i, al-Risālah, Aḥmad Muhammad Shākir, ed., (Cairo: Bulāq, 1891) 430; Ibn Jarīr al-Tabarī, Jāmi 'al-Bayān 'an Ta'wīl Āy al-Qur'ān (Beirut: Dār al-Kutub al- 'Ilmīyah, 1995) v. 3, 18, where he cites a hadìth to this effect on the Companion al-Dahhāak.

37. Ibid., 13 .

38. See for details, Suheyl Umar, The Religious Other, 366.

39. See A. Afsaruddin, "Semantic Purview of Jihād," in Huda, Crescent and Dov,e 48.

40. Ibid.

41. Ibid.

42. For an interesting discussion consult Asma Afsaruddin, "Semantic Purview of Jihād", 48.

43. Joel Hayward, Qur'anic Concepts of the Ethics of Warfare, 9.

44. See A. Afsaruddin, "Semantic Purview of Jihād", 51. 
45. See Mustafa Akyol, Islam Without Extremes: A Muslim Case for Liberty (New York \& London: W.W. Norton \& Company, 2011) 174.

46. Nikkie R. Kiddie, "The Revolt of Islam, 1700-1993," in Islam: Critical Concepts in Sociology, vol. 2, Bryan S. Turner, ed., (Oxford: Routledge, 2003) 89.

47. Bernard Lewis, The Crisis of Islam: Holy War and Unholy Terror (London: Widenfeld \& Nicholson, 2000) 30 .

48. B. Lewis, The Crisis of Islam, 30.

49. Karen Armstrong, Holy War: The Crusades and Their Impact on Today's World (New York: Anchor Books, 2001) 178.

50. Ibid., 259.

51. Mustafa Akyol, Islam Without Extremes, 193.

52. N. Kiddie, "The Revolt of Islam", 90.

53. Seyyed Hossein Nasr, "Islam's Attitude Toward Other Religions in History", in Muhammad Suheyl Umar, ed., The Religious Other: Towards a Muslim Theology of Other Religions in a Post-Prophetic Age (Lahore: Iqbal Academy, 2008) 129-130.

54. As of this writing an initial framework agreement has been reached between the Philippine government of President Aquino and the Moro Islamic Liberation Front to end the forty-year-old conflict. Malaysia has successfully mediated this agreement.

55. See Chandra Muzaffar, Exploring Religion in Our Time (Pulau Pinang: Penerbit Universiti Sains Malaysia, 2011) 20.

56. Arthur Schneier, "Religion and Interfaith Conflict," in David Smock, Ed., Interfaith Dialogue and Peacebuilding (Washington D.C.: United States Institute of Peace, 2002) 112.

57. Imam Feisal Abdul Rauf, What's Right With Islam Is What's Right With America (HarperSanFrancisco, 2004) 276. 